\title{
Whitefly Resistance Traits Derived from the Wild Tomato Solanum pimpinellifolium Affect the Preference and Feeding Behavior of Bemisia tabaci and Reduce the Spread of Tomato yellow leaf curl virus
}

\author{
M. J. Rodríguez-López, E. Garzo, J. P. Bonani, A. Fereres, R. Fernández-Muñoz, and E. Moriones
}

First, fifth, and sixth authors: Instituto de Hortofruticultura Subtropical y Mediterránea "La Mayora" (IHSM-UMA-CSIC), Consejo Superior de Investigaciones Científicas, E-29750 Algarrobo-Costa, Málaga, Spain; and second, third, and fourth authors: Instituto de Ciencias Agrarias, Centro de Ciencias Medioambientales, Consejo Superior de Investigaciones Científicas, c/ Serrano 115 dpdo, E-28006 Madrid, Spain.

Accepted for publication 17 May 2011.

\begin{abstract}
Rodríguez-López, M. J., Garzo, E., Bonani, J. P., Fereres, A., FernándezMuñoz, R., and Moriones, E. 2011. Whitefly resistance traits derived from the wild tomato Solanum pimpinellifolium affect the preference and feeding behavior of Bemisia tabaci and reduce the spread of Tomato yellow leaf curl virus. Phytopathology 101:1191-1201.

Breeding of tomato genotypes that limit whitefly (Bemisia tabaci) access and feeding might reduce the spread of Tomato yellow leaf curl virus (TYLCV), a begomovirus (genus Begomovirus, family Geminiviridae) that is the causal agent of tomato yellow leaf curl disease. TYLCV is restricted to the phloem and is transmitted in a persistent

sucroses from the wild tomato Solanum pimpinellifolium accession TO937 into the genetic background of the whitefly- and virus-susceptible tomato cultivar Moneymaker. Results of preference bioassays with ABL 14-8 versus Moneymaker indicated that presence of type IV glandular trichomes and the production of acylsucrose deterred the landing and settling of B. tabaci on ABL 14-8. Moreover, electrical penetration graph studies indicated that $B$. tabaci adults spent more time in nonprobing activities and showed a reduced ability to start probing. Such behavior resulted in a reduced ability to reach the phloem. The superficial type of resistance observed in ABL 14-8 against B. tabaci probing significantly reduced primary and secondary spread of TYLCV.
\end{abstract} manner by B. tabaci. The tomato breeding line ABL 14-8 was developed by introgressing type IV leaf glandular trichomes and secretion of acyl-

The whitefly (Hemiptera: Aleyrodidae) Bemisia tabaci Gennadius is one of the most destructive pests of horticultural crops and ornamental plants worldwide $(8,13)$. Direct crop damage from this insect is caused by phloem feeding that depletes reserves and causes physiological alterations in the plants. In heavy infestations, secondary damage can be caused through honeydew excretion, which supports fungal growth in the form of sooty mold; sooty mold blocks sunlight and reduces photosynthesis (18). The most serious damage caused by this pest, however, is due to its role as a vector of plant viruses $(7,21)$.

Begomoviruses (genus Begomovirus; family Geminiviridae) (65) cause severe diseases in economically and socially important crops (58). These viruses are transmitted by $B$. tabaci in a persistent circulative manner (21), and since the early 1990s, these viruses have rapidly emerged as serious problems around the world $(15,45)$. Their emergence was associated with the emergence of the insect vector, B. tabaci, which was spread and increased because of increased plant trading between distantly separated geographical regions and changes in agricultural practices (62).

Diseases caused by begomoviruses are economically important for tomato (Solanum lycopersicum L.) production in tropical and subtropical regions (20). Tomato yellow leaf curl virus (TYLCV) is one of the most widespread of the begomoviruses that cause tomato yellow leaf curl disease (TYLCD) $(12,44)$. TYLCV is mainly restricted to the tomato phloem tissues, and during

Corresponding author: E. Moriones; E-mail address: moriones@eelm.csic.es

doi:10.1094/PHYTO-01-11-0028

(c) 2011 The American Phytopathological Society
Additional keywords: acylsugars, disease control. epidemics, adult $B$. tabaci may transmit the virus from infected plants to healthy plants during feeding $(11,21)$.

In addition to TYLCV, tomato can be naturally infected by more than 60 other begomoviruses $(15,28)$. Begomovirus-caused diseases are managed primarily by controlling vector populations through intensive chemical spray and/or physical barriers. As is the case for other vector-transmitted viruses (49), conventional whitefly control with insecticides is often ineffective at reducing virus spread. This method of control also has deleterious environmental consequences and selects for insecticide-resistant populations in B. tabaci $(9,60)$. Therefore, the best option to reduce begomovirus damage is the use of virus-resistant cultivars (70). Unfortunately, there are few plant resistance genes that completely protect tomato against begomovirus infection, and this greatly limits the germplasm available for breeding. Particular accessions of some Solanum section Lycopersicon wild tomato species have been found to be resistant to TYLCV, and these resistance sources have been used to breed virus-resistant commercial tomatoes $(31,50-52,71)$. Alternative management tools are needed, especially in warm conditions when whitefly populations can be extremely high, and one attractive alternative is the use of vector-resistant cultivars (29), which has been explored in tomato for $B$. tabaci $(14,46,63)$. The question arises as to whether resistance against the insect vector will limit begomovirus spread, because vector resistance can in some cases increase virus transmission (4). Vector-resistant cultivars, however, have helped to reduce the spread of other plant viruses. For example, cultivars of pepper (Capsicum annuum L.) that are resistant to thrips (Thysanoptera: Thripidae) experience reduced infection by Tomato spotted wilt virus (genus Tospovirus, family Bunyaviridae) even though the cultivars are fully susceptible to the virus (38). 
The specific virus-vector interactions that determine begomovirus transmission are complex, involving not only the virus and vector but also the host plant and environment. In addition to the nature of virus acquisition and virus association with the vector, vector landing and probing on the plant source as well as vector feeding patterns may influence the efficiency of virus transmission $(16,21)$. Therefore, changes in the host that alter vector behavior could change transmission and disease dynamics (24).

Plant traits that affect insect performance can play an important role in determining insect resistance (22). As phloem sap feeders, whiteflies penetrate the leaf tissue with their mouthparts, covering the distance from the epidermis to the phloem vessel intercellularly, and feed on the sieve elements (53). Plant resistance can occur at successive plant tissue levels, from the surface to the phloem sieve element. Therefore, the study of stylet penetration behavior can provide clues about mechanisms involved in resistance.

To study the feeding behavior of sap-sucking insects, McLean and Kinsey (40) developed a device to record electrical events related to stylet penetration and ingestion activities inside plant tissue. The electronic monitoring system that they developed used an AC circuit, and the system was later modified to use a DC circuit by Tjallingii (66). Tjallingii (67) named this technique as the electrical penetration graph (EPG) technique, and the EPG technique has been successfully used to study the feeding behavior of adult whiteflies of Trialeurodes vaporariorum Westwood and B. tabaci $(23,25-27,32,33)$. The technique consists of assembling an electric circuit that includes the insect and the plant. Stereotypical voltage fluctuations (waveforms) are associated with specific stylet activities, based on correlations with other techniques that indicate the precise stylet tip position or the occurrence of ingestion, egestion, or salivation (72). The EPG data can be used to locate the tissues in which plant resistance factors are operating (68).

Natural resistance to multiple arthropod pests based on secretions by the different types of glandular trichomes (35) present on stems and leaves of tomato and its wild relatives has been long described (reviewed in 63). The accession TO-937 of the wild species Solanum pimpinellifolium L., a close relative to the cultivated tomato, is resistant to the two-spotted spider mite (17) because it possesses type IV glandular trichomes that produce acylsucroses (2). This resistance trait was easily introgressed into the susceptible tomato cultivar Moneymaker after several steps of recurrent backcrossing with selection for high leaf type IV trichome density and acylsucrose production to obtain the ABL 14-8 tomato breeding line. Interestingly, TO-937 and ABL 14-8 also exhibited resistance to $B$. tabaci infestation (1). Because TYLCD spread in tomato might depend on B. tabaci infestation levels $(6,21)$, breeding for $B$. tabaci resistance in tomato varieties could help control TYLCD. The success of this approach, however, requires that vector resistance reduces virus spread (47). In this study, we examined antixenosis resistance traits of the breeding line ABL 14-8 to adult $B$. tabaci and determined whether those can help to limit TYLCD spread in tomato. The specific objectives were (i) to assess the host-acceptance behavior of $B$. tabaci in the tomato line ABL 14-8 (which has type IV glandular trichomes that produce acylsucroses), (ii) to compare the probing and feeding behavior of B. tabaci on ABL 14-8 and its susceptible near-isogenic line Moneymaker, and (iii) to determine whether ABL 14-8 reduces TYLCV spread.

\section{MATERIALS AND METHODS}

Tomato plants, virus isolate, and whitefly population. Two near-isogenic tomato lines were used: the whitefly- and virussusceptible tomato Moneymaker and the advanced backcross line ABL 14-8. For ABL 14-8, the presence of type IV glandular trichomes and acylsucrose secretion were derived by three re- current backcrosses and selfing steps from the wild tomato $S$. pimpinellifolium accession TO-937 to the cultivar Moneymaker, which lacks those traits (17). The Estación Experimental "La Mayora"-CSIC germplasm collection accession TO-937 is an inbred line derived from $S$. pimpinellifolium material collected by our colleague J. Cuartero at $50 \mathrm{~m}$ altitude on the coastal plain of Lambayeque Department, Peru in 1983. The original accession segregated widely for density of glandular trichomes and it was fixed by four consecutive selfing and selection steps. In conducting experiments, we had to consider growth stage of plants and time of year because full expression of acylsucrose production in the B. tabaci-resistance-donor genotype TO-937 occurs only after the 10-leaf growth stage and during warm seasons (1).

The infectious clone of the TYLCV begomovirus associated with TYLCD, TYLCV-IL[ES:Alm:Pep:99], has been described elsewhere (43). Tomato plants infected with this clone were obtained by Agrobacterium tumefaciens-mediated inoculation (agroinoculation) using the stem puncture method described by Monci et al. (41). Healthy $B$ tabaci individuals were obtained from a Q biotype colony that originated from field-collected individuals from Málaga, Spain. Whiteflies were reared on melon (Cucumis melo L. 'ANC42', Estación Experimental "La Mayora"-CSIC germplasm collection or cultivar Primal $F_{1}, S \& G$ Vegetables) plants within wooden cages covered with insect-proof nets, in an insectproof glasshouse with temperature control $\left(22\right.$ to $27^{\circ} \mathrm{C}$ day and 17 to $20^{\circ} \mathrm{C}$ night) and supplemental light when needed, or in a growth chamber $\left(25^{\circ} \mathrm{C}\right.$ day and $20^{\circ} \mathrm{C}$ night, $70 \% \mathrm{RH}$, and a $16: 8 \mathrm{~h}$ photoperiod at $250 \mu \mathrm{mol} \mathrm{s} \mathrm{s}^{-1} \mathrm{~m}^{-2}$ photosynthetically active radiation). Viruliferous whiteflies were obtained by providing $B$. tabaci adults a 48-h acquisition access period on TYLCV-infected tomato Moneymaker plants.

Whitefly settling under no-choice and free-choice conditions. Detached leaflets from Moneymaker and ABL 14-8 plants at 4- and 10-leaf-growth stages were used. Six leaflets of one genotype and growth stage were placed in a circle in an independent plastic tray $(25 \times 25 \mathrm{~cm})$ in no-choice experiments. For free-choice experiments, three leaflets of each genotype and growth stage were placed in an alternate design in a single plastic tray; in these free-choice experiments, different growth stages were placed in different trays. During both experiments, each leaflet petiolule was inserted in a plastic dish $(2 \mathrm{~cm}$ diameter $\times$ $1 \mathrm{~cm}$ high) filled with nutrient solution $(0.25 \mathrm{~g} /$ liter of Nutrichem 60, Miller Chemical, Hanover, PA) to maintain leaflet turgor. Leaflets were placed abaxial surface down and at an angle with the horizontal (so that both leaflet surfaces were freely accessible to whiteflies), with their tips directed to the center of the circle formed by the leaflets. Thirty adult whiteflies (five whiteflies per leaflet tested, without sex distinction) were released in the center of the circle after a short cold treatment $\left(10 \mathrm{~min}\right.$ at $\left.4^{\circ} \mathrm{C}\right)$ to facilitate handling. Each plastic tray was then covered with a plastic lid with an opening covered with muslin for ventilation. The trays were placed in a growth chamber $\left(25^{\circ} \mathrm{C}\right.$ and a $16: 8 \mathrm{~h}$ photoperiod). The number of whiteflies that settled on each leaflet was counted at $0.5,1,2,4,8,24$, and $48 \mathrm{~h}$ after release. Freechoice and no-choice experiments were replicated 12 times. Mean number of whiteflies per six leaflets in no-choice or in three leaflets in free-choice experiments was calculated. Data were subjected to a Mann-Whitney U test using the statistical software SPSS for Windows, version 17.0 (SPSS Inc., Chicago, IL).

EPGs of whitefly adults on Moneymaker and ABL 14-8. The DC-EPG technique was used to monitor probing and feeding activities of female $B$. tabaci adults as described by Jiang et al. (26), on the third leaf from the apex of Moneymaker and ABL 14-8 plants at the 10-leaf growth stage. The recordings were conducted for 6-h under constant light at $23 \pm 2{ }^{\circ} \mathrm{C}$ and started immediately after whiteflies were placed on the tomato leaf. Each whitefly was used only once, and each plant was used a maximum of three times for EPG recording. Data acquisition and screen display 
were controlled by PROBE 3.0 for Windows software (Laboratory of Entomology, Wageningen University), and data were analyzed with this same software after data conversion. The whitefly feeding-associated waveforms, which were previously correlated with behavioral events in $T$. vaporariorum by Janssen et al. (23) and in B. tabaci by Jiang et al. (26), were identified. These were waveform NP, nonprobing behavior (no stylet contact with the leaf tissue); waveform $\mathrm{C}$, intercellular apoplastic stylet pathway where the insects show a cyclic activity of mechanical stylet penetration and secretion of saliva; waveform pd (potential drop), represents brief (4 to $12 \mathrm{~s}$ intracellular stylet punctures during the pathway phase $(\mathrm{C})$. There are two waveforms related with the phloem activity: waveform E1, salivation into phloem sieve elements at the beginning of the phloem phase (25); waveform E2, correlated with passive phloem sap uptake from the sieve elements that is comparable to E2 of aphids (54). EPG sequential and nonsequential events related to the pathway ( $\mathrm{C}$ and pd) and phloem phase (E1 and E2) were extracted from each recording by a workbook for automatic parameter calculation of EPG data (59). The term "probe" refers to any type of event during the period in which the stylet of an individual insect is located in the plant tissue, and "no probe" refers to the event with no waveform (indicating that the individual has its stylet outside plant tissues). Data from approximately 20 individual adult whiteflies were recorded and compared for each tomato genotype. The EPG variables (mean \pm standard error) were calculated as described in Backus et al. (5): PPW, proportion of individuals that produced the waveform type; NRWI, number of waveform events per insect; WDI, waveform duration (min) per insect; and WDE, waveform duration (min) per event. EPG variables of the two genotypes were compared by the Mann-Whitney U test.

Primary spread of TYLCV to Moneymaker and ABL 14-8 plants. Primary spread of TYLCV, i.e., virus spread to healthy plants from an external source viruliferous vectors (10), was simulated in medium-scale experiments conducted within insectproof net, walk-in structures $(5 \times 5 \times 2 \mathrm{~m})$ built within a tunnel net house. Preliminary small-scale studies in insect-proof cages established that the effective dose $90\left(\mathrm{ED}_{90}\right.$, the minimum number of adult viruliferous whiteflies per test plant that resulted in a $90 \%$ TYLCV infection) in four-leaf growth stage susceptible tomato Moneymaker plants after a 48-h inoculation access period (IAP) was 15 (unpublished data). Therefore, primary spread experiments were conducted by releasing 15 adult viruliferous whiteflies per test plant for a 48-h IAP; viruliferous whiteflies were placed in the center of a circle ( $2 \mathrm{~m}$ diameter) of 22 healthy Moneymaker or ABL 14-8 plants at the 4- or 10-leaf growth stage in a no-choice test design. Two experiments were conducted at "La Mayora" Experimental Station (Málaga, southern coastal Spain), one in summer (a warm, dry season with long-day conditions, $25^{\circ} \mathrm{C} / 20^{\circ} \mathrm{C}$ average day and night temperatures, and $35^{\circ} \mathrm{C} / 18^{\circ} \mathrm{C}$ average maximum and minimum temperatures) and one in autumn (a temperate, more humid season with short-day conditions, $22^{\circ} \mathrm{C} / 18^{\circ} \mathrm{C}$ average day and night temperatures, and $25^{\circ} \mathrm{C} / 15^{\circ} \mathrm{C}$ average maximum and minimum temperatures), with plants at 4- and 10-leaf growth stages. After the IAP, plants were treated with insecticide and then transferred to an insect-proof glasshouse until analyzed. Type IV trichome density and acylsucrose accumulation were evaluated in assayed plants (see below). Virus presence was scored on each test plant at weekly intervals until 28 days postinoculation (dpi) by tissue blot hybridization (see below). Data in the form of numbers of infected and noninfected plants were analyzed by the generalized linear model (Logit as the link function and Binomial as the underlying distribution), and data from the two genotypes were compared by the least-squares (LS) means test. The Statistical Analysis System for Windows, version 9.1 (SAS Institute, Cary, NC), was used.

Secondary spread of TYLCV from infected Moneymaker and ABL 14-8 source plants. Secondary spread of TYLCV from infected Moneymaker or ABL 14-8 plants, i.e., virus spread from virus-infected source plants to healthy plants (10), was measured within insect-proof net walk-in structures (see above). In each treatment, three TYLCV-infected virus source plants were placed in a walk-in structure so that they formed a triangle (with $60 \mathrm{~cm}$ between the three plants) in the center of a circle ( $2 \mathrm{~m}$ diameter) of 22 healthy Moneymaker or ABL 14-8 test plants. Virus-source plants (Moneymaker and ABL 14-8 plants agroinoculated with TYLCV 15 days earlier) had equivalent virus levels in apical leaves and were selected after Southern blot hybridization analysis (see below). Healthy B. tabaci adult individuals (30 whiteflies per test plant) were then released in the center of the triangle of virus-source plants, and after 96-h, test plants were treated with insecticide and transferred to an insect-proof glasshouse until analyzed. A single experiment was conducted during summer, in a no-choice test design with Moneymaker or ABL 14-8 as test plants at the 10-leaf growth stage and including treatments using 10-leaf growth stage Moneymaker or ABL 14-8 as virus source plants. Virus presence was scored on each test plant by tissue blot hybridization (see below) at weekly intervals until 28 dpi. Infection data were compared by the LS means tests as explained above.

Virus detection by molecular hybridization. TYLCV-IL was detected with tissue blot, dot blot, or Southern blot hybridizations. For tissue blot hybridization, freshly made cross-sections of petioles of the youngest newly emerged leaf of test plants were squashed on nylon positively charged membranes (Roche Diagnostics, Mannheim, Germany). For dot blot or Southern blot hybridizations, nucleic acids were obtained and analyzed according to Monci et al. (41). After blotting, nucleic acids were UVcross-linked. Hybridization was performed at $65^{\circ} \mathrm{C}$ according to the manufacturer's instructions using a digoxigenin (DIG)-labeled DNA probe able to detect the TYLCV-IL strain. The probe comprising the intergenic region was prepared by polymerase chain reaction with primers MA-30 (5'-GAGCACTTAGGATATGTGA GG-3', nucleotides 2,566 to 2,586) and MA-31 (5'-AGTGGA TCCCACATATTGC-3', nucleotides 170 to 152 ) based on the sequence of the TYLCV clone pPORT2 (GenBank accession no. AF105975) (48). Washing steps and detection with the alkalinephosphatase chemiluminescent substrate CDP-Star (Roche Diagnostics) were performed as recommended by the manufacturer.

Observation of trichomes and quantification of acylsucrose accumulation. The high density of type IV glandular trichomes in ABL 14-8 was confirmed by both light and scanning electron microscopy (SEM). Trichome density was estimated and acylsucrose production was quantified in leaflets from the third leaf from the apex. Leaf surface acylsucrose was extracted and quantified as described by Alba et al. (2) following the colorimetric method by Goffreda et al. (19).

\section{RESULTS}

B. tabaci prefers landing on genotypes without type IV glandular trichomes. Presence of traits associated with $B$. tabaci resistance was evaluated in ABL 14-8 and Moneymaker plants. Whereas type IV glandular trichomes were present on both leaf surfaces of ABL 14-8 plants, they were absent on Moneymaker leaves (Fig. 1A). On ABL 14-8 leaves, type IV trichome densities did not differ between plants at the 4- or 10-leaf growth stages or between growing seasons (data not shown). Also, ABL 14-8 leaf extracts but not those of Moneymaker contained acylsucrose quantities above the measurement background; high acylsucrose levels were detected in ABL 14-8 plants at the 10-leaf growth stage and under warm-season conditions but much lower levels were detected at the four-leaf growth stage, especially under temperate-season conditions (Fig. 1B).

In no-choice treatments, $B$. tabaci settling was significantly lower at most time points on leaflets of ABL 14-8 than on those of 


\section{A}

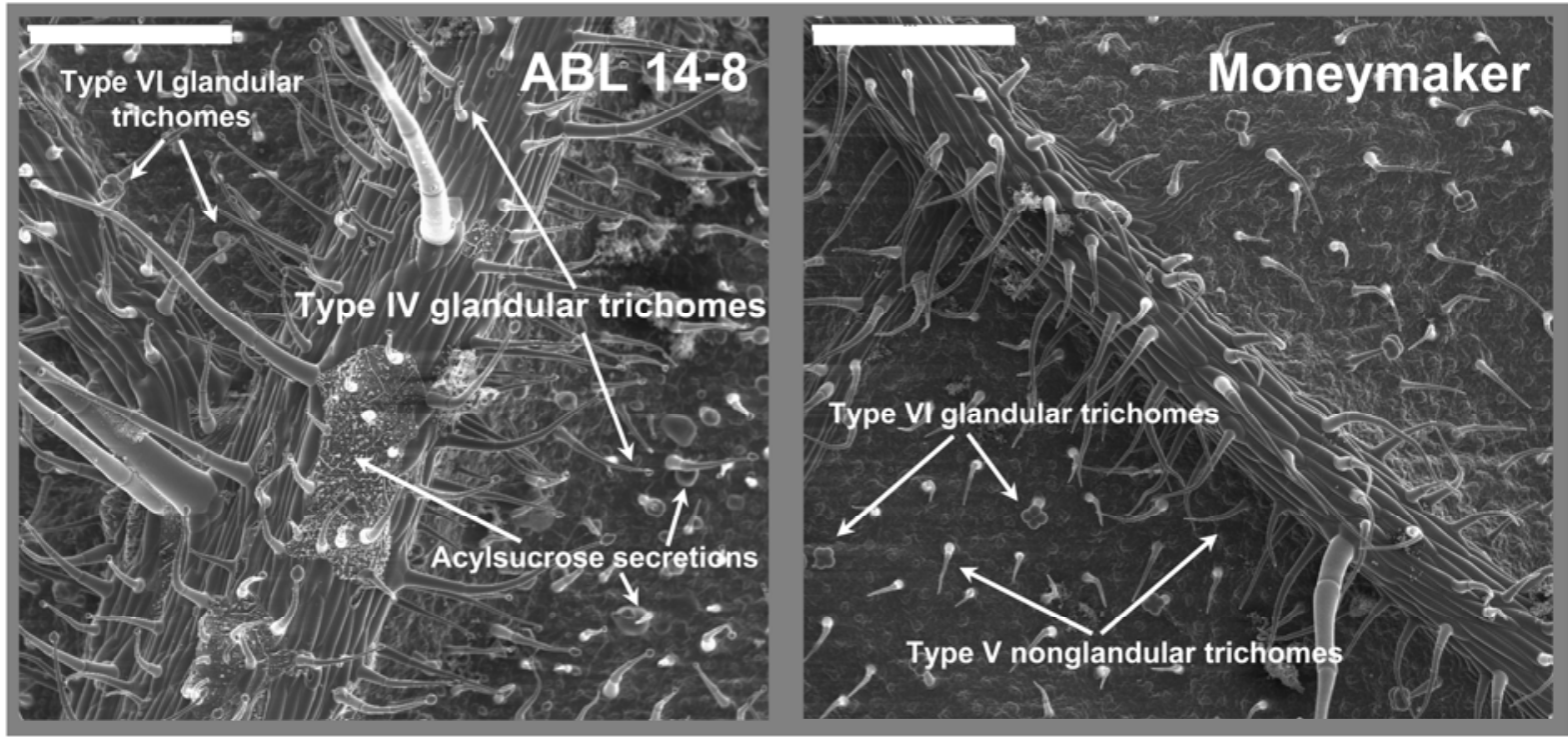

B

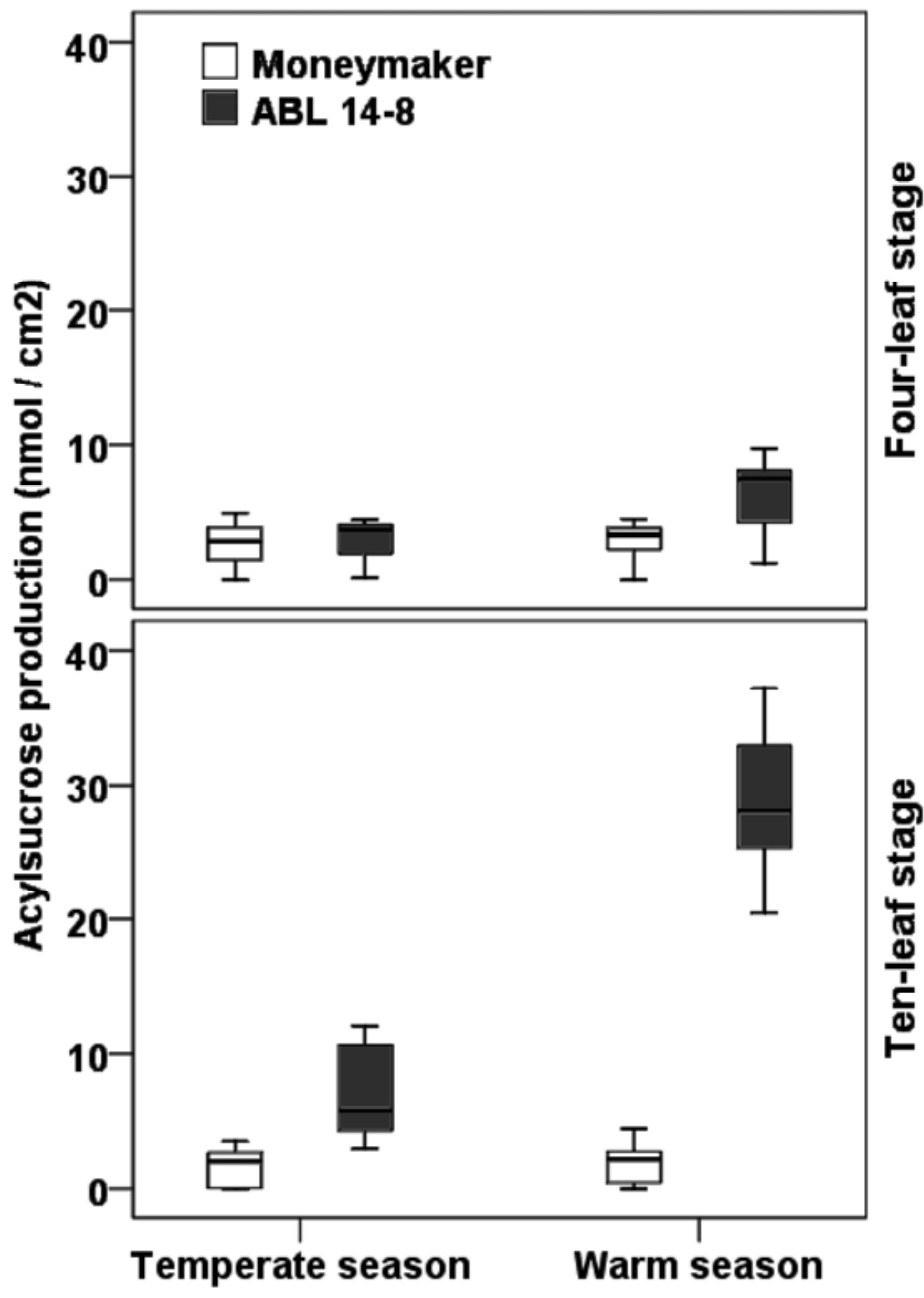

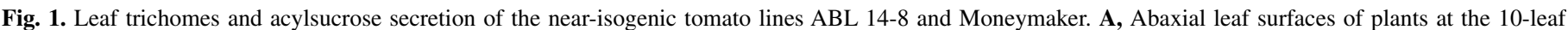

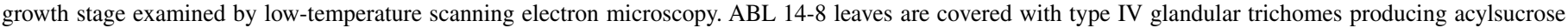

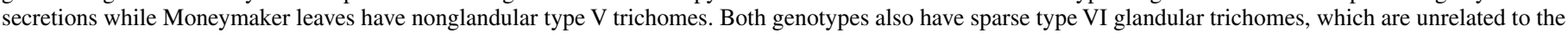

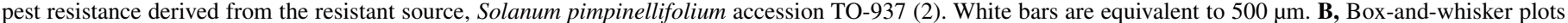

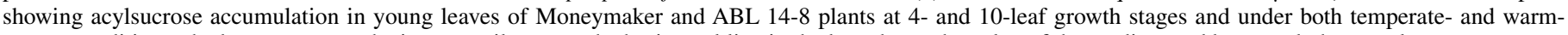
season conditions; the box represents the interquartile range, the horizontal line in the box shows the value of the median, and bars mark the actual ranges. 
Moneymaker at the 10-leaf growth stage (which is when high acylsucrose production occurs for ABL 14-8) but not at the four-leaf growth stage (Fig. 2A). Similar results were obtained in free-choice treatments; i.e., whiteflies could rapidly discriminate between the ABL 14-8 and Moneymaker leaflets at the 10-leaf growth stage but not at the four-leaf growth stage (Fig. 2B).

Electrical monitoring of $B$. tabaci probing and feeding behavior on Moneymaker and ABL 14-8. EPG studies were conducted with plants at the 10-leaf growth stage exhibiting high acylsucrose production. EPG variables in Table 1 have been sorted into two categories: nonsequential and sequential. The major differences between the feeding behavior of $B$. tabaci on Moneymaker and ABL 14-8 plants were in the number and duration of nonprobing events. Whiteflies made significantly less number of nonprobing events but of much longer duration on ABL 14-8 than on Moneymaker. The longer duration of nonprobing events in ABL 14-8 was mainly caused by a longer nonprobing time at the beginning of the EPG recording, as indicated by a longer "time to first probe from start of EPG" (Table 1). We also observed that the total number of probes per insect, the number of brief probes $(<1 \mathrm{~min})$, and the number of probes ( $<3 \mathrm{~min}$ ) after the first phloem contact were significantly lower in ABL 14-8 than in Moneymaker (Table 1). However, no significant difference was observed in the duration of probing events $(4.2 \pm$ 2.2 versus $3.3 \pm 1.5$ for ABL and Moneymaker, respectively; $P=$ 0.132). All of this supports the idea that ABL 14-8 has traits of "superficial resistance" (i.e., resistance expressed before stylet penetration) against $B$. tabaci.

The phloem activity of $B$. tabaci, either salivation ("E1") or ingestion ("E2"), was less frequent in ABL 14-8 than in Moneymaker (Table 1). This differential response at the phloem level seems more related to plant epidermal factors that made the phloem more difficult to reach in ABL 14-8 than to phloem resistant factors (see below). Interestingly, because "time from the beginning of that probe to first E" did not differ between the two plants $(P=0.199)$, it seems that whiteflies were not impeded from reaching the phloem of ABL 14-8 plants once the "stylet pathway" ("C") had begun. Moreover, when whiteflies reached the phloem tissue, the duration of phloem sap ingestion ("E2") did not differ between ABL 14-8 and Moneymaker, suggesting that phloem sap factors are not involved in the resistance. The duration of sieve element salivation, however, was shorter in ABL 14-8 than in Moneymaker as indicated by significantly $(P=$ 0.022 ) smaller values of duration of "E1" and "total duration of E1 followed by E2" per insect.

Determining TYLCV susceptibility level in Moneymaker and ABL 14-8. For a correct assessment of the effect of insect resistance on the spread of TYLCV, the plant genotypes that are compared should be equally susceptible to the virus. Virus susceptibility is equivalent for ABL 14-8 and Moneymaker as indicated by Southern blot analysis of young noninoculated tissues of plants agroinoculated with TYLCV at the 4- or 10-leaf growth stages. TYLCV accumulation was similar in Moneymaker and
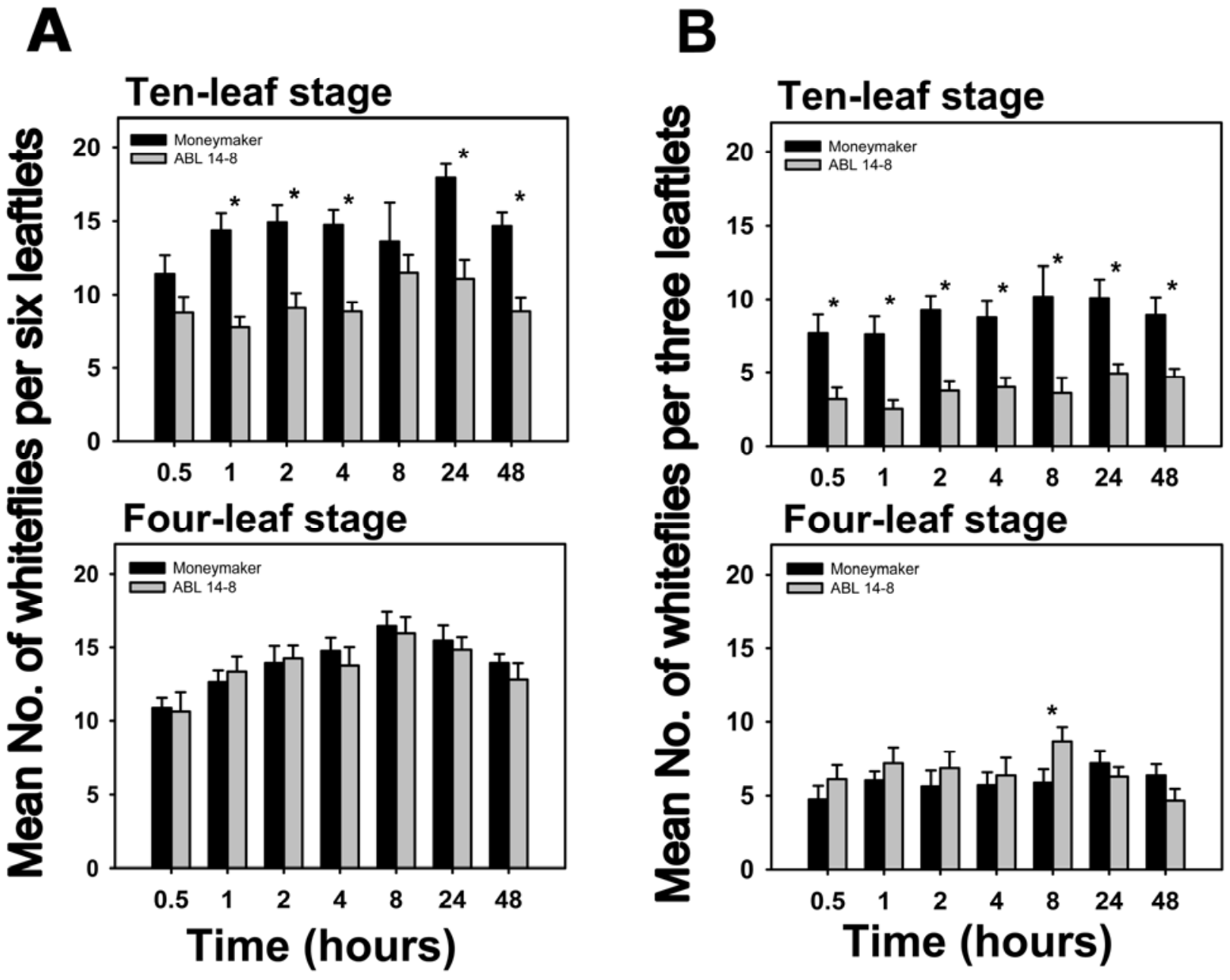

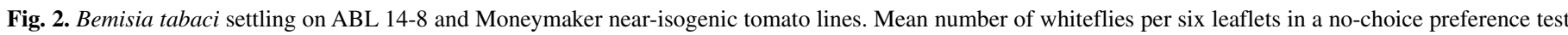

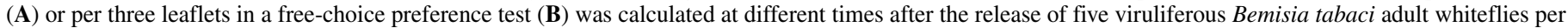

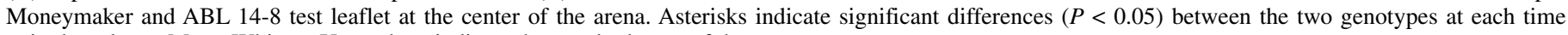
point based on a Mann-Whitney U test; bars indicate the standard error of the mean. 
ABL 14-8 plants (Fig. 3). Similar TYLCD symptoms also were observed in Moneymaker- and ABL 14-8-infected plants.

Primary spread of TYLCV to Moneymaker and ABL 14-8 plants. In a medium-scale experiment that quantified the effect of plant genotype on primary spread of TYLCV (virus was introduced to arenas in the form of viruliferous $B$. tabaci, and each arena had only one plant genotype), fewer ABL 14-8 than Moneymaker plants were infected by TYLCV regardless of plant growth stage or seasonal condition except for four-leaf stage under temperate conditions (Fig. 4A). Differences were greatest when plants were at the 10-leaf growth stage. Therefore, B. tabaci resistance in ABL 14-8 significantly reduced but did not eliminate the primary spread of TYLCV.
Secondary spread of TYLCV from infected source plants to Moneymaker and ABL 14-8 plants. Because the previous results indicated that viruliferous $B$. tabaci could transmit TYLCV to ABL 14-8 plants, it was important to assess whether the insect resistance could limit the secondary virus spread from infected source plants to nearby healthy plants. Secondary spread of TYLCV was assessed for ABL 14-8 and Moneymaker plants at the 10-leaf growth stage and under warm season conditions when whiteflies adults are more active and efficiently spread the virus. In the conditions tested, ABL 14-8-infected plants were less efficient virus sources for secondary virus spread than Moneymaker-infected plants (Fig. 4B). For example, about $73 \%$ of the Moneymaker test plants (plants that were healthy when placed in

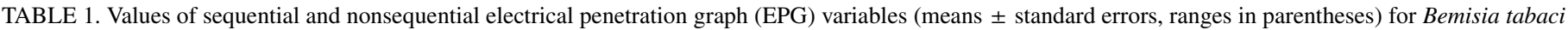
probing behavior on abaxial leaf surfaces of 10-leaf growth stage Moneymaker and ABL 14-8 plants during a 6-h recording ${ }^{\mathrm{a}}$

\begin{tabular}{|c|c|c|c|c|c|c|c|c|}
\hline Variables & Genotype & PPW & NWEI & $P^{\mathrm{b}}$ & WDI & $P$ & WDE & $P$ \\
\hline \multicolumn{9}{|l|}{ Nonsequential variables } \\
\hline \multirow[t]{2}{*}{ Nonprobe } & ABL $14-8$ & $17 / 17$ & $38.2 \pm 9.8(4-175)$ & 0.023 & $203.2 \pm 21.2(73.0-343.2)$ & 0.669 & $18.7 \pm 5.9(1.6-85.2)$ & 0.034 \\
\hline & Moneymaker & $19 / 19$ & $57.9 \pm 11.2(10-240)$ & & $179.0 \pm 16.8(31.39-271.7)$ & & $4.5 \pm 0.8(0.9-12.3)$ & \\
\hline \multirow[t]{2}{*}{ Probe } & ABL $14-8$ & $17 / 17$ & $37.5 \pm 9.8(3-174)$ & 0.022 & $156.3 \pm 21.2(16.61-286.5)$ & 0.716 & $4.2 \pm 2.2(5.5-1.7)$ & 0.132 \\
\hline & Moneymaker & $19 / 19$ & $53.7 \pm 11.2(10-239)$ & & $179.0 \pm 17.0(84.47-328.1)$ & & $3.3 \pm 1.5(8.5-1.4)$ & \\
\hline \multirow[t]{2}{*}{$\mathrm{C}$} & ABL $14-8$ & $17 / 17$ & $39.2 \pm 9.9(4-176)$ & 0.025 & $103.4 \pm 15.5(8.0-217.4)$ & 0.384 & $4.5 \pm 1.2(0.8-18.0)$ & 0.235 \\
\hline & Moneymaker & $19 / 19$ & $59.6 \pm 11.2(13-240)$ & & $119.2 \pm 9.7(51.7-206.8)$ & & $3.3 \pm 0.9(0.6-15.9)$ & \\
\hline \multirow[t]{2}{*}{$\mathrm{pd}^{\mathrm{c}}$} & ABL 14-8 & $10 / 17$ & $4.0 \pm 1.7(0-28)$ & 0.034 & $43.0 \pm 14.5(5.9-132.3)$ & 0.128 & $6.2 \pm 0.8(4.3-12.2)$ & 0.022 \\
\hline & Moneymaker & $14 / 19$ & $9.1 \pm 11.2(0-25)$ & & $58.5 \pm 9.8(13.9-137.5)$ & & $4.8 \pm 0.6(2.8-11.4)$ & \\
\hline \multirow[t]{2}{*}{ E1 } & ABL 14-8 & $7 / 17$ & $0.6 \pm 0.2(0-2)$ & 0.056 & $1.3 \pm 0.6(0.1-4.5)$ & 0.022 & $1.1 \pm 0.6(0.1-4.5)$ & 0.091 \\
\hline & Moneymaker & $12 / 19$ & $1.7 \pm 0.4(0-5)$ & & $7.0 \pm 2.0(0.1-24.0)$ & & $2.9 \pm 1.0(0.1-12.0)$ & \\
\hline \multirow[t]{2}{*}{ E2 } & ABL 14-8 & $7 / 17$ & $0.5 \pm 0.2(0-2)$ & 0.049 & $75.7 \pm 28.5(12.1-228.8)$ & 0.800 & $67.0 \pm 28.3(6.0-228.8)$ & 0.272 \\
\hline & Moneymaker & $12 / 19$ & $1.4 \pm 0.3(0-4)$ & & $73.9 \pm 20.9(0.7-218.7)$ & & $33.8 \pm 7.1(0.3-72.9)$ & \\
\hline \multicolumn{9}{|l|}{ Sequential variables } \\
\hline \multicolumn{9}{|l|}{ Time to first probe from } \\
\hline \multirow[t]{2}{*}{ start of EPG } & ABL 14-8 & $17 / 17$ & & & $16.0 \pm 8.4(0.2-144.3)$ & 0.055 & & \\
\hline & Moneymaker & $19 / 19$ & & & $6.0 \pm 2.6(0.1-45.5)$ & & & \\
\hline \multirow[t]{2}{*}{ Duration of first probe } & ABL $14-8$ & $17 / 17$ & & & $1.8 \pm 0.6(0.1-10.3)$ & 0.800 & & \\
\hline & Moneymaker & $19 / 19$ & & & $1.4 \pm 0.4(0.2-6.0)$ & & & \\
\hline \multirow[t]{2}{*}{ Duration of second probe } & ABL $14-8$ & $17 / 17$ & & & $1.1 \pm 0.3(0.1-4.5)$ & 0.623 & & \\
\hline & Moneymaker & $19 / 19$ & & & $1.9 \pm 0.6(0.1-10.7)$ & & & \\
\hline \multicolumn{9}{|l|}{ Number of brief probes } \\
\hline \multirow[t]{2}{*}{$(<1 \mathrm{~min})$} & ABL 14-8 & $17 / 17$ & $22.4 \pm 7.4(1-131)$ & 0.040 & & & & \\
\hline & Moneymaker & $19 / 19$ & $37.7 \pm 9.7(2-198)$ & & & & & \\
\hline \multirow{3}{*}{$\begin{array}{l}\text { Time from the beginning of } \\
\text { that probe to first } \mathrm{E}\end{array}$} & & & & & & & & \\
\hline & ABL 14-8 & $7 / 17$ & & & $221.8 \pm 41.3(4.5-359.9)$ & 0.199 & & \\
\hline & Moneymaker & $12 / 19$ & & & $142.6 \pm 39.0(3.1-359.8)$ & & & \\
\hline \multicolumn{9}{|l|}{ Time from first probe to } \\
\hline \multirow[t]{2}{*}{ first $\mathrm{E}$} & ABL 14-8 & $7 / 17$ & & & $277.7 \pm 28.6(15.9-359.9)$ & 0.199 & & \\
\hline & Moneymaker & $12 / 19$ & & & $220.3 \pm 29.1(36.5-359.8)$ & & & \\
\hline \multicolumn{9}{|l|}{ Number of probes to the } \\
\hline \multirow[t]{2}{*}{ first E1 } & ABL 14-8 & $7 / 17$ & $19.8 \pm 10.6(0-174)$ & 0.315 & & & & \\
\hline & Moneymaker & $12 / 19$ & $16.4 \pm 4.0(0-47)$ & & & & & \\
\hline \multicolumn{9}{|l|}{ Number of probes after } \\
\hline first $\mathrm{E}$ & ABL $14-8$ & $7 / 17$ & $0.6 \pm 0.2(0-2)$ & 0.056 & & & & \\
\hline & Moneymaker & $12 / 19$ & $1.7 \pm 0.4(0-5)$ & & & & & \\
\hline Number of probes $(<3 \mathrm{~min})$ & & & & & & & & \\
\hline after first $\mathrm{E}$ & ABL $14-8$ & $7 / 17$ & $1.8 \pm 1.1(0-16)$ & 0.011 & & & & \\
\hline & Moneymaker & $12 / 19$ & $12.2 \pm 3.9(0-56)$ & & & & & \\
\hline Total duration of E1 & & & & & & & & \\
\hline followed by E2 & ABL 14-8 & $7 / 17$ & & & $1.3 \pm 0.6(0.1-4.5)$ & 0.022 & & \\
\hline & Moneymaker & $12 / 19$ & & & $6.5 \pm 1.9(0.1-24.0)$ & & & \\
\hline Number of sustained E2 & & & & & & & & \\
\hline$(>10 \mathrm{~min})$ & ABL 14-8 & $7 / 17$ & $0.4 \pm 0.1(0-2)$ & 0.174 & & & & \\
\hline & Moneymaker & $12 / 19$ & $0.8 \pm 0.2(0-3)$ & & & & & \\
\hline $\begin{array}{l}\text { Total duration of E1 } \\
\text { followed by sustained E2 }\end{array}$ & & & & & & & & \\
\hline & ABL $14-8$ & $7 / 17$ & & & $1.1 \pm 0.6(0.0-4.5)$ & 0.866 & & \\
\hline & Moneymaker & $12 / 19$ & & & $4.1 \pm 1.3(0.0-13.3)$ & & & \\
\hline
\end{tabular}

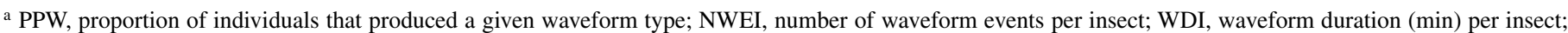
WDE, waveform duration ( $\mathrm{min}$ ) per event. Nonprobe, nonprobing activity, no stylet contact with the plant tissue; probe, stylet insertion into the plant of any duration or purpose; waveform $\mathrm{C}$, intercellular apoplastic stylet pathway where the insects show a cyclic activity of mechanical stylet penetration and secretion of saliva; waveform pd (potential drop), represents brief (4 to $12 \mathrm{~s}$ ) intracellular stylet punctures during the pathway phase (C). There are two waveforms related with the phloem activity: waveform E1, salivation into phloem sieve elements at the beginning of the phloem phase (25); waveform E2, correlated with passive phloem sap uptake from the sieve elements that is comparable to E2 of aphids (54).

b Statistical comparisons between the two plant genotypes for each parameter were made with the nonparametric Mann Whitney U test.

c Potential drop (pd) duration is expressed in seconds. 
the arena) were infected at $28 \mathrm{dpi}$ when Moneymaker was the virus source but only $22 \%$ of the Moneymaker test plants were infected when ABL 14-8 was the virus source. TYLCV incidence was lower with ABL 14-8 test plants than with Moneymaker test plants regardless of the virus source plant genotype. Therefore, the $B$. tabaci resistance in ABL 14-8 might help to reduce the secondary spread of TYLCV. Much limited TYLCV spread to ABL 14-8 was also observed regardless of the virus source, reinforcing the primary spread constraint effect observed for this genotype.

\section{DISCUSSION}

This study demonstrates that antixenosis resistance to adult $B$. tabaci in tomato, a resistance based on type IV glandular trichomes and acylsucrose secretions, reduces the spread of TYLCD. The mechanisms of resistance to adult $B$. tabaci in the tomato ABL 14-8 were associated with prephloem (epidermis) factors that reduced attractiveness of the plant to the insect and therefore reduce the efficiency of $B$. tabaci-phloem interaction. Previous studies with wild tomato species suggested that the presence of glandular trichomes on leaves was associated with reduced attractiveness of B. tabaci to some $S$. habrochaites S. Knapp \& D.M. Spooner accessions (64) and was also related to leaf chemicals (46). Moreover, Maluf et al. (37) demonstrated that foliar acylsugar content was a major component of the resistance to three tomato pests (including $\mathrm{B}$. tabaci) in tomato genotypes derived from S. pennellii. Fernández-Muñoz et al. (17) and Alba (1) and Alba et al. (2) also demonstrated that foliar acylsugars in $S$. pimpinellifolium TO-937, which was the resistance donor of the ABL 14-8 line, were sufficient to confer resistance to the twospotted spider mite and $B$. tabaci. The advantages of using the $S$. pimpinellifolium accession rather than green-fruited wild tomato species as a source of resistance is that $S$. pimpinellifolium is redfruited, self-compatible, and very closely related to the cultivated tomato, which greatly facilitates the breeding of desired horticultural qualities into the resistant tomato (55).

Our results indicate that the breeding line ABL 14-8, derived from TO-937 in a $S$. lycopersicum background, had a deterrent effect on $B$. tabaci, which was associated with the secretion of acylsucrose produced by type IV glandular trichomes. Deterrence was fully expressed in ABL 14-8 plants at the 10-leaf growth stage, when high acylsucrose production occurred. In contrast, deterrence was much lower at the four-leaf stage, a stage at which acylsugar levels were still relatively low. It should be emphasized that growth stage and season are crucial for acylsucrose production as shown here (Fig. 1B) and described for the resistance source TO-937 in relation to repellence to the two-spotted spider mite by Alba et al. (2). This should be carefully considered for the correct use of the arthropod pest resistance trait present in ABL 14-8. Similar acylsugar-mediated nonpreference pest resistance was observed in various Solanaceae species $(47,56)$ and was associated with $B$. tabaci resistance in tomato breeding lines derived from $S$. pennellii (34). The resistance described here would then be useful to supplement other B. tabaci control measures such as use of insecticides (49), although the effect on the life history traits of this insect needs to be evaluated before deployment in this sense. This resistance also might help to
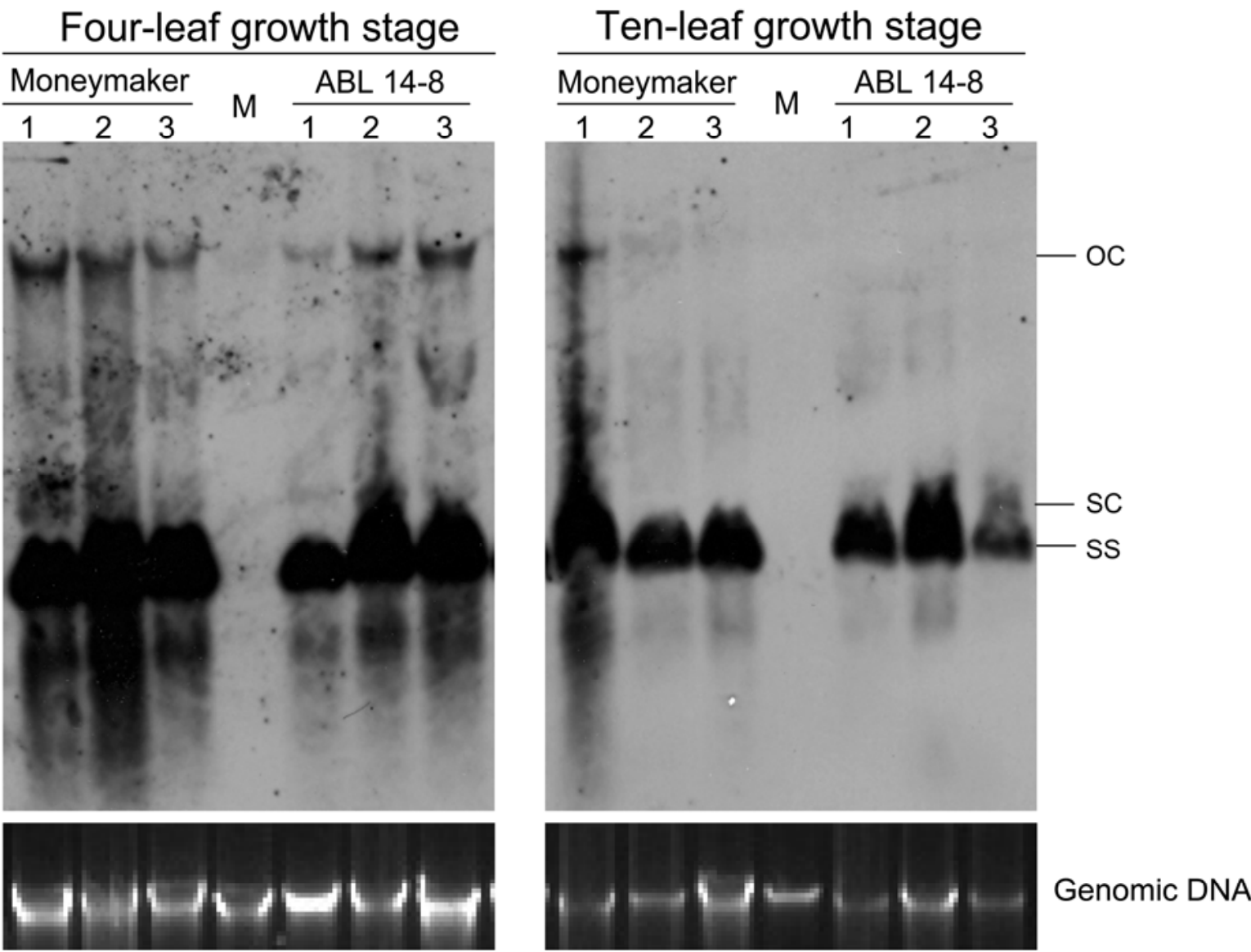

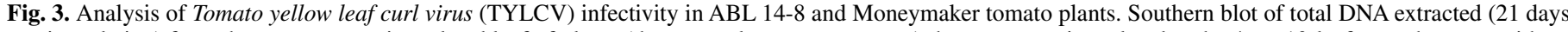

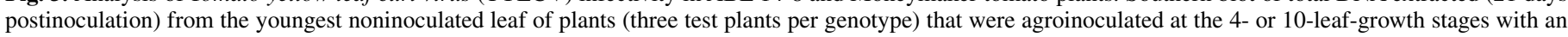

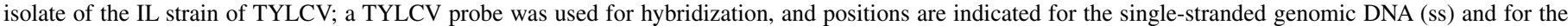

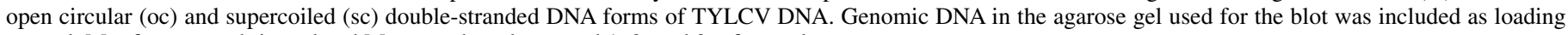
control. M refers to mock-inoculated Moneymaker plants, and 1, 2, and 3 refer to plants. 
reduce the irregular ripening disorder caused by $B$. tabaci on tomato (61), by lowering whitefly infestations. The latter would be especially important for virus-resistant tomatoes if growers do not bother to control whiteflies.

The possibility of using deterrence to cause antixenosis of insect vectors (30) and thus to reduce virus-associated crop losses has been highlighted (47). In addition to antixenosis, the feeding behavior of the insect after it lands on a plant can also affect virus acquisition and transmission. Adult $B$. tabaci acquire and transmit TYLCD-associated begomoviruses while feeding on the phloem of tomato plants (7). In our analysis of B. tabaci probing and feeding behavior, the EPG data indicated that the phloem was

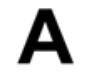

Temperate season
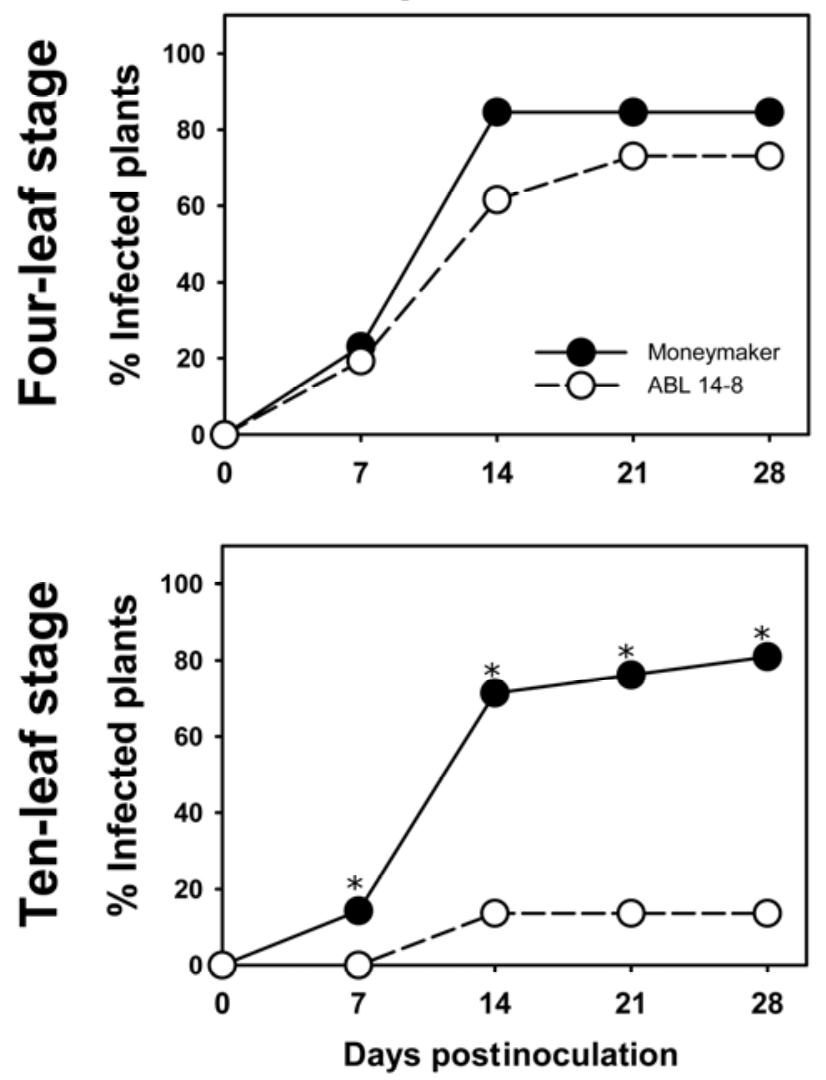

Warm season
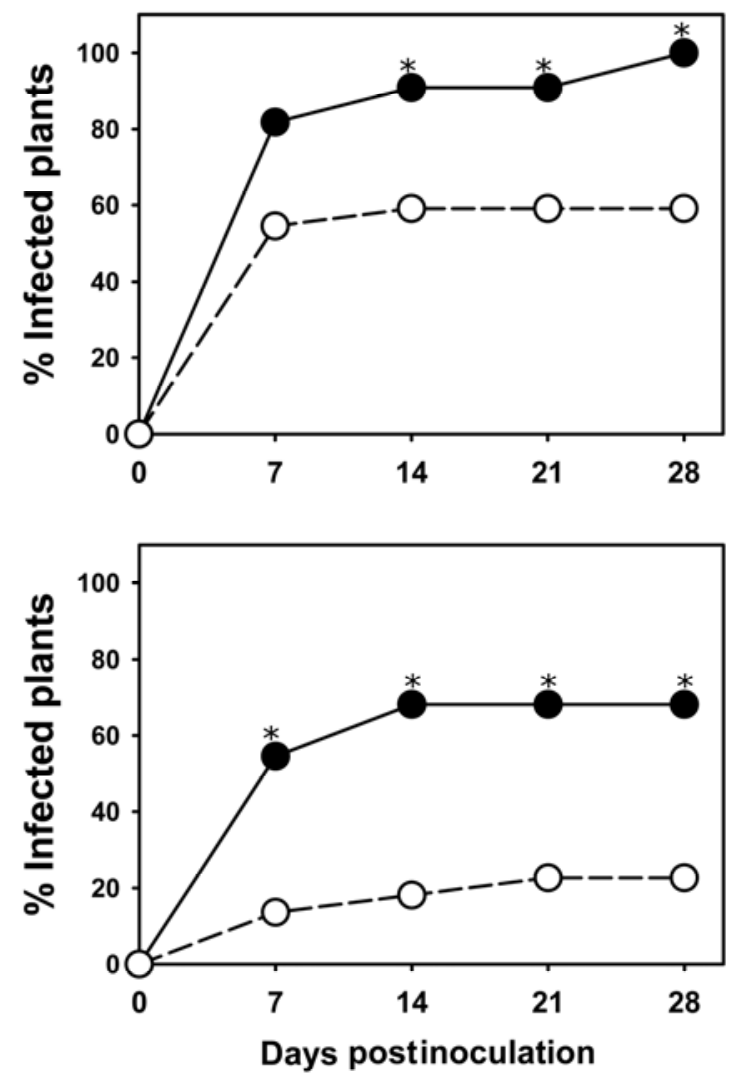

B

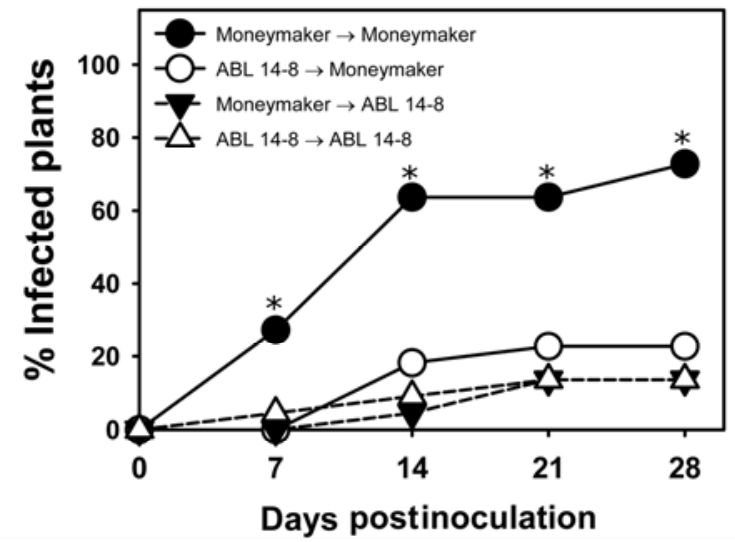

Fig. 4. Percentages of Tomato yellow leaf curl virus (TYLCV)-infected plants in experiments measuring virus spread to and from tomato genotypes with or without type IV glandular trichomes and acylsucrose secretions. A, Primary spread of TYLCV to healthy ABL 14-8 or Moneymaker test plants (22 plants in a nochoice test) at either 10- or 4-leaf growth stages in medium-scale experiments conducted under temperate- and warm-season conditions. Virus transmission was measured at several times after viruliferous whiteflies (15 Bemisia tabaci biotype Q adult whiteflies per test plant) were given a 48-h feeding and inoculation access period. Asterisks indicate significant differences in TYLCV incidence between the two genotypes at each time (L-S mean tests, $P<0.05$ ). B, Secondary spread of TYLCV from 10-leaf growth stage Moneymaker- or ABL 14-8-infected source plants to 10-leaf growth stage Moneymaker or ABL 14-8 healthy test plants (22 plants in a no-choice test) under warm-season conditions. Virus transmission to test plants was measured at several times after nonviruliferous whiteflies (30 B. tabaci biotype Q adult whiteflies per test plant) were given a 96-h feeding and inoculation access period. Asterisks indicate significant differences in TYLCV incidence at each times (least-squares mean tests, $P<0.05$ ), which appeared only between the combination Moneymaker (source)-Moneymaker (test) and the other three combinations. 
accessed less efficiently in ABL 14-8 leaves than in Moneymaker leaves; the reduced access to the phloem of ABL 14-8 leaves was mainly associated with factors evident before stylet penetration. Surface (epidermis) factors on ABL 14-8 leaves deterred whiteflies from probing and starting phloem feeding, and no postpenetration phloem-resistance factors seemed to be involved in the response. The whiteflies continued nonprobing activities for a longer period on leaves of the resistant ABL 14-8 than on the susceptible Moneymaker, and there were fewer probes in ABL 14-8 than in Moneymaker. Consequently, B. tabaci stylets reached the phloem less efficiently in ABL 14-8 than in Moneymaker. It should be stressed, however, that phloem access, and therefore the possibility of TYLCV acquisition and transmission, was not completely blocked in ABL 14-8. After the stylet reached the phloem, however, the duration of salivation into sieve elements was shorter in ABL 14-8 than in Moneymaker; this could also reduce virus transmission because duration of salivation into the sieve elements was the most significant variable associated with inoculation of TYLCV by B. tabaci (25). Less efficient phloem feeding as observed here, generally reduces acquisition of phloem-restricted viruses (16).

Management of viruses through alteration of vector efficiency is an interesting alternative for virus control $(57,74)$. Although vector resistance in plants might decrease virus incidence (47), Madden et al. (36) stressed that the effect of vector resistance on disease development strongly depends on the transmission mode. Vector resistance could increase the transmission of nonpersistently transmitted viruses because nonpersistent viruses can be transmitted as the vectors probe for suitable feeding sites among plants (4). For persistently transmitted viruses like begomoviruses, however, vector resistance to plant feeding should reduce acquisition and inoculation rates and therefore should decrease virus spread. B. tabaci feeds on the phloem of host plants (22) where TYLCV is confined (11). Therefore, the reduced salivation and ingestion (as documented by EPG data) when $B$. tabaci feeds on the phloem of ABL 14-8 plants should reduce the efficiency of virus acquisition and transmission, as observed in other systems $(21,39)$. This, together with the lower preference observed in $B$. tabaci for ABL 14-8 plants, might reduce the spread of TYLCV in this genotype. In fact, we demonstrated that primary TYLCV spread was reduced in ABL 14-8, with dramatic differences observed in virus spread for plants at the 10-leaf growth stage, when the resistance traits are fully expressed. Although based on a single experiment, a restricted TYLCV spread from ABL 14-8 plants that could get infected was also suggested in secondary spread studies. Therefore, the results obtained here indicate that the B. tabaci resistance present in ABL 14-8 plants can be sufficient to reduce the incidence and spread of TYLCV, even though ABL 14-8 is fully susceptible to the virus. As suggested by Van den Bosch et al. (69), vector resistant lines that reduce virus acquisition and inoculation such as that shown here, might also help to exert minimal selection pressure on the virus to evolve more harmful strains.

In conclusion, type IV glandular trichomes and acylsucrose production in ABL 14-8 tomato provide resistance to adult $B$. tabaci infestation and reduce TYLCV spread. This resistance should be useful for controlling TYLCD epidemics in tomato crops and might be especially effective because the expression of the protective trait was greatest with warm and dry conditions typical of summer, when TYLCD incidence is maximum in regions with large $B$. tabaci populations (42). The resistance traits reported here seem not to ensure effective control for earlier plant developmental stages or for colder periods. Nevertheless, pyramiding of this resistance with virus-resistance genes (70) should generate a more effective control of TYLCD, given that incomplete vector resistance combined with even slight virus resistance has significantly improved the control of other viral diseases $(29,57)$. Then, deployment of B. tabaci-resistant plant genotypes should probably be considered a supplemental control for TYLCV and other viruses transmitted by this insect. Further investigation is warranted on the effectiveness of vector-mediated resistance against other tomato-infecting begomoviruses or other whiteflytransmitted viruses such as criniviruses (genus Crinivirus, family Closteroviridae) (73) or torradoviruses (genus Torradovirus) (3) that infect tomato and could differ in transmission mode.

\section{ACKNOWLEDGMENTS}

This work was partially financed by Ministerio de Ciencia e Innovación projects AGL2007-66062-C02-01/AGR, AGL2007-66760-C0202/AGR, AGL2007-66399-CO3-02/AGR, and AGL2010-22287-C0201/AGR, Spain (cofinanced by FEDER). This work was also partially supported by fundings for research groups AGR-214 and AGR-129 from Consejería de Innovación y Ciencia, Junta de Andalucía, Spain (cofinanced by FEDER-FSE). M. J. Rodríguez-López was recipient of a $\mathrm{Ph} . \mathrm{D}$. fellowship and additional funding from the Ministerio de Ciencia e Innovación, which supported a brief stay in the laboratory of A. Fereres. We thank E. R. Bejarano for providing the TYLCV-IL[ES:Alm:Pep:99] agroinfectious clone, W. M. Wintermantel for helpful discussion and critical reading of the manuscript, and B. Jaffee for manuscript editing.

\section{LITERATURE CITED}

1. Alba, J. M. 2006. Herencia de los mecanismos de resistencia a araña roja en tomate. Ph.D. Thesis. Facultad de Ciencias, Universidad de Málaga.

2. Alba, J. M., Montserrat, M., and Fernández-Muñoz, R. 2009. Resistance to the two-spotted spider mite (Tetranychus urticae) by acylsucroses of wild tomato (Solanum pimpinellifolium) trichomes studied in a recombinant inbred line population. Exp. Appl. Acarol. 47:35-47.

3. Amari, K., González-Ibeas, D., Gómez, P., Sempere, R. N., Sánchez-Pina, M. A., Aranda, M. A., Díaz-Pendon, J. A., Navas-Castillo, J., Moriones, E., Blanca, J., Hernandez-Gallardo, M. D., and Anastasio, G. 2008. Tomato torrado virus is transmitted by Bemisia tabaci and infects pepper and eggplant in addition to tomato. Plant Dis. 92:1139.

4. Atiri, G. I., Ekpot, E. J. A., and Thottappilly, G. 1984. The effect of aphidresistance in cowpea on infestation and development of Aphis craccivora and the transmission of cowpea aphid-borne mosaic virus. Ann. Appl. Biol. 104:339-346.

5. Backus, E. A., Cline, A. R., Ellerseick, M. R., and Serrano, M. S. 2007. Lygus hesperus (Hemiptera: Miridae) feeding on cotton: New methods and parameters for analysis of nonsequential electrical penetration graph data. Ann. Entomol. Soc. Am. 100:296-310.

6. Brown, J. 2007. The Bemisia tabaci complex: Genetic and phenotypic variation and relevance to TYLCV-vector interactions. Pages 25-56 in: Tomato yellow leaf curl virus Disease Management, Molecular Biology, Breeding for Resistance. H. Czosnek, ed. Springer, The Netherlands.

7. Brown, J. K., and Czosnek, H. 2002. Whitefly transmission of plant viruses. Adv. Bot. Res. 36:65-100.

8. Brown, J. K., Frolich, D. R., and Rosell, R. C. 1995. The sweet-potato or silverleaf whiteflies-Biotypes of Bemisia tabaci or a species complex. Annu. Rev. Entomol. 40:511-534.

9. Cahill, M., Gorman, K., Day, S., Denholm, I., Elbert, A., and Nauen, R. 1996. Baseline determination and detection of resistance to imidacloprid in Bemisia tabaci (Homoptera: Aleyrodidae). Bull. Entomol. Res. 86:343349.

10. Campbell, C. L., and Madden, L. V. 1990. Introduction to Plant Disease Epidemiology. John Wiley \& Sons, New York.

11. Cohen, S., and Antignus, Y. 1994. Tomato yellow leaf curl virus, a whitefly-borne geminivirus of tomatoes. Adv. Dis. Vector Res. 10:259288.

12. Cohen, S., and Lapidot, M. 2007. Appearance and expansion of TYLCV: A historical point of view. Pages 3-12 in: Tomato yellow leaf curl virus Disease Management, Molecular Biology, Breeding for Resistance. H. Czosnek, ed. Springer, The Netherlands.

13. Dalton, R. 2006. Whitefly infestations: The Christmas invasion. Nature 443:898-900.

14. Delatte, H., Holota, H., Reynaud, B., and Dintinger, J. 2006. Characterisation of a quantitative resistance to vector transmission of Tomato yellow leaf curl virus in Lycopersicon pimpinellifolium. Eur. J. Plant Pathol. 114:245-253.

15. Fauquet, C., Briddon, R., Brown, J., Moriones, E., Stanley, J., Zerbini, M., and Zhou, X. 2008. Geminivirus strain demarcation and nomenclature. Arch. Virol. 153:783-821.

16. Fereres, A., and Moreno, A. 2009. Behavioral aspects influencing plant virus transmission by homopteran insects. Virus Res. 141:158-168. 
17. Fernández-Muñoz, R., Salinas, M., Alvarez, M., and Cuartero, J. 2003. Inheritance of resistance to two-spotted spider mite and glandular leaf trichomes in wild tomato Lycopersicon pimpinellifolium (Jusl.) Mill. J. Am. Soc. Hort. Sci. 128:188-195.

18. Gerling, D. 1990. Whiteflies: Their Bionomics, Pest Status and Management. Andover, Intercept, UK.

19. Goffreda, J. C., Steffens, J. C., and Mutschler, M. A. 1990. Association of epicuticular sugars with aphid resistance in hybrids with wild tomato. J. Am. Soc. Hortic. Sci. 115:161-165.

20. Hanssen, I. M., Lapidot, M., and Thomma, B. P. H. J. 2010. Emerging viral diseases of tomato crops. Mol. Plant-Microbe Interact. 23:539-548.

21. Hogenhout, S. A., Ammar, E. D., Whitfield, A. E., and Redinbaugh, M. G. 2008. Insect vector interactions with persistently transmitted viruses. Annu. Rev. Phytopathol. 46:327-359.

22. Inbar, M., and Gerling, D. 2008. Plant-mediated interactions between whiteflies, herbivores, and natural enemies. Annu. Rev. Entomol. 53:431448.

23. Janssen, J. A. M., Tjallingii, W. F., and van Lenteren, J. C. 1989. Electrical recording and ultrastructure of stylet penetration by the greenhouse whitefly. Entomol. Exp. Appl. 52:69-81.

24. Jeger, M. J., Holt, J., van den Bosch, F., and Madden, L. V. 2004. Epidemiology of insect-transmitted plant viruses: Modelling disease dynamics and control interventions. Phys. Entomol. 29:291-304.

25. Jiang, Y. X., de Blas, C., Barrios, L., and Fereres, A. 2000. Correlation between whitefly feeding behavior and TYLCV transmission. Ann. Entomol. Soc. Am. 93:573-579.

26. Jiang, Y. X., Lei, H., Collar, J. L., Martin, B., Muñiz, M., and Fereres, A. 1999. Probing and feeding behaviour of two distinct biotypes of Bemisia tabaci (Homoptera: Aleyrodidae) on tomato plants. J. Econ. Entomol. 92:357-366.

27. Johnson, D. D., and Waker, G. P. 1999. Intracellular punctures by the adult whitefly Bemisia argentifolii on DC and AC electronic feeding monitors. Entomol. Exp. Appl. 92:257-270.

28. Jones, D. R. 2003. Plant viruses transmitted by whiteflies. Eur. J. Plant Pathol. 109:195-219.

29. Jones, A. T. 1987. Control of virus infection in crop plants through vector resistance: A review of achievements, prospects and problems. Ann. Appl. Biol. 111:745-772.

30. Kogan, M., and Ortman, E. E. 1978. Antixenosis-A new term proposed to replace Painter's "nonpreference" modality of resistance. Bull. Entomol. Soc. Am. 24:175-176.

31. Lapidot, M., and Friedmann, M. 2002. Breeding for resistance to whitefly-transmitted geminiviruses. Ann. Appl. Biol. 140:109-127.

32. Lei, H., Tjallingii, F., and van Lenteren, J. C. 1998. Probing and feeding characteristics of the greenhouse whitefly in association with host-plant acceptance and whitefly strains. Entomol. Exp. Appl. 88:73-80.

33. Lei, H., van Lenteren, J. C., and Tjallingii, F. 1999. Analysis of resistance in tomato and sweet pepper against the greenhouse whitefly using electrically monitored and visually observed probing and feeding behaviour. Entomol. Exp. Appl. 92:299-309.

34. Lobato-Ortiz, R., Schuster, D. J., and Mutschler, M. A. 2007. Second generation of tomato acylsugar lines with reduction in $S$. pennellii DNA content are resistant to silverleaf whitefly and improved for fruit characters. Hortscience 42:1015

35. Luckwill, L. C. 1943. The genus Lycopersicon. An historical, biological, and taxonomic survey of the wild and cultivated tomatoes. Aberdeen Univ. Stud. No. 120

36. Madden, L. V., Jeger, M. J., and van den Bosch, F. 2000. A theoretical assessment of the effects of vector-virus transmission mechanism on plant virus disease epidemics. Phytopathology 90:576-594.

37. Maluf, R. W., Maciel, G. M., Gomes, L. A. A., Cardoso, M. G., Gonçalves, L. D., da Silva, E. C., and Knapp, M. 2010. Broad-spectrum arthropod resistance in hybrids between high- and low-acylsugar tomato lines. Crop Sci. 50:439-450.

38. Maris, P. C., Joosten, N. N., Goldbach, R. W., and Peters, D. 2003. Restricted spread of Tomato spotted wilt virus in thrips-resistant pepper. Phytopathology 93:1223-1227.

39. Maris, P. C., Joosten, N. N., Peters, D., and Goldbach, R. W. 2003. Thrips resistance in pepper and its consequences for the acquisition and inoculation of Tomato spotted wilt virus by the western flower thrips. Phytopathology 93:96-101.

40. McLean, D. L., and Kinsey, M. G. 1964. A technique for electronically recording aphid feeding and salivation. Nature 202:1358-1359.

41. Monci, F., García-Andrés, S., Maldonado, J. A., and Moriones, E. 2005. Resistance to monopartite begomoviruses associated with the bean leaf crumple disease in Phaseolus vulgaris controlled by a single dominant gene. Phytopathology 95:819-826.

42. Morales, F. J., and Jones, P. G. 2004. The ecology and epidemiology of whitefly-transmitted viruses in Latin America. Virus Res. 100:57-65.

43. Morilla, G., Janssen, D., García-Andrés, S., Moriones, E., Cuadrado, I.
M., and Bejarano, E. R. 2005. Pepper (Capsicum annuum) is a dead-end host for Tomato yellow leaf curl virus. Phytopathology 95:1089-1097.

44. Moriones, E., and Navas-Castillo, J. 2000. Tomato yellow leaf curl virus, an emerging virus complex causing epidemics worldwide. Virus Res. 71:123-134.

45. Moriones, E., Navas-Castillo, J., and Díaz-Pendón, J. A. 2011. Emergence of begomovirus diseases. Pages 301-320 in: Recent Advances in Plant Virology. C. Caranta, M. A. Aranda, M. Tepfer, and J. López-Moya, eds. Caister Academic Press, Norfolk, UK

46. Muigai, S. G., Schuster, D. J., Snyder, J. C., Scott, J. W., Bassett, M. J., and McAuslane, H. J. 2002. Mechanisms of resistance in Lycopersicon germplasm to the whitefly Bemisia argentifolii. Phytoparasitica 30:347360.

47. Mutschler, M. A., and Wintermantel, W. M. 2006. Reducing virus associated crop loss through resistance to insect vectors. Pages 241-260 in: Natural Resistance Mechanisms of Plant Viruses. G. Loebenstein and J. P. Carr, eds. Springer, The Netherlands.

48. Navas-Castillo, J., Sánchez-Campos, S., Noris, E., Louro, D., Accotto, G. P., and Moriones, E. 2000. Natural recombination between Tomato yellow leaf curl virus-Is and Tomato leaf curl virus. J. Gen. Virol. $81: 2797-2801$

49. Perring, T. M., Gruenhagen, N. M., and Farrar, C. A. 1999. Management of plant viral diseases through chemical control of insect vectors. Annu. Rev. Entomol. 44:457-481.

50. Picó, B., Díez, M. J., and Nuez, F. 1996. Viral diseases causing the greatest economic losses to the tomato crop. 2. The Tomato yellow leaf curl virus-A review. Sci. Hortic. 67:151-196.

51. Picó, B., Ferriol, M., Díez, M. J., and Nuez, F. 1999. Developing tomato breeding lines resistant to Tomato yellow leaf curl virus. Plant Breed. 118:537-542.

52. Pilowsky, M., and Cohen, S. 2000. Screening additional wild tomatoes for resistance to the whitefly-borne Tomato yellow leaf curl virus. Acta Phys. Plant. 22:351-353

53. Pollard, D. G. 1995 Feeding habits of the cotton whitefly, Bemisia tabaci Genn. (Homoptera: Aleyrodidae). Ann. Appl. Biol. 43:664-671.

54. Prado, E., and Tjallingii, F. 1994. Aphids activities during sieve element punctures. Entomol. Exp. Appl. 72:157-165.

55. Rick, C. M. 1979. Biosystematic studies in Lycopersicon and closely related species of Solanum. Pages 667-678 in: The Biology, Taxonomy of Solanaceae. J. G. Hawkes, R. N. Lester, and A. D. Skelding, eds. Academic Press, New York.

56. Rodríguez, A. E., Tingey, W. M., and Mutschler, M. A. 1993. Acylsugars of Lycopersicon pennellii deter settling and feeding of the green peach aphid (Homoptera: Aphididae). J. Econ. Entomol. 86:34-39.

57. Romanow, L. R., Moyer, J. W., and Kennedy, G. G. 1986. Alteration of efficiencies of acquisition and inoculation of watermelon mosaic virus 2 by plant resistance to the virus and to an aphid vector. Phytopathology 76:1276-1281.

58. Rybicki, E. P., and Pietersen, G. 1999. Plant virus disease problems in the developing world. Adv. Virus Res. 53:127-175.

59. Sarriá, E., Cid, M., Garzo, E., and Fereres, A. 2009. Workbook for automatic parameter calculation of EPG data. Comput. Electron. Agric. 67:35-42.

60. Schuster, D. J., Mann, R. S., Toapanta, M., Cordero, R., Thompson, S., and Morris, R. F. 2008. Monitoring of imidacloprid resistance in biotype B of Bemisia tabaci in Florida. J. Insect Sci. 8:42-43.

61. Schuster, D. J., Mueller, T. F., Kring, J. B., and Price, J. F. 1990. Relationship of the sweetpotato whitefly to a new tomato fruit disorder in Florida. Hortscience 25:1618-1620.

62. Seal, S. E., van den Bosch, F., and Jeger, M. J. 2006. Factors influencing begomovirus evolution and their increasing global significance: Implications for sustainable control. Crit. Rev. Plant Sci. 25:23-46.

63. Simmons, A. T., and Gurr, G. M. 2005. Trichomes of Lycopersicon species and their hybrids: Effects on pests and natural enemies. Agric. Forest Entomol. 7:265-276.

64. Snyder, J. C., Simmons, A. M., and Thacker, R. R. 1998. Attractancy and ovipositional response of adult Bemisia argentifolii (Homoptera: Aleyrodidae) to type IV trichome density on leaves of Lycopersicon hirsutum grown in three day-length regimes. J. Entomol. Sci. 33:270-281.

65. Stanley, J., Bisaro, D. M., Briddon, R. W., Brown, J. K., Fauquet, C. M., Harrison, B. D., Rybicki, E. P., and Stenger, D. C. 2005. Family Geminiviridae. Pages 301-326 in: Virus Taxonomy. Eighth Report of the International Committee on Taxonomy of Viruses. C. M. Fauquet, M. A. Mayo, J. Maniloff, U. Desselberger, and L. A. Ball, eds. Academic Press, San Diego.

66. Tjallingii, W. F. 1978. Electronic recording of penetration behavior by aphids. Entomol. Exp. Appl. 24:721-730.

67. Tjallingii, W. F. 1990. Continuous recording of stylet penetration activities by aphids. Pages 89-99 in: Aphid-Plant Genotype Interactions. R. K. Campbell and R. D. Eikenbary, eds. Elsevier, Amsterdam. 
68. Tjallingii, W. F. 1995. Aphid-plant interactions: What goes on in the depth of the tissues? Proc. Exp. Appl. Entomol. 6:163-169.

69. Van den Bosch, F., Akudibilah, G., Seal, S., and Jeger, M. 2006. Host resistance and the evolutionary response of plant viruses. J. Appl. Ecol. 43:503-516.

70. Vidavski, F. 2007. Exploitation of resistance genes found in wild tomato species to produce resistant cultivars; pile up of resistant genes. Pages 363-372 in: Tomato yellow leaf curl virus Disease Management, Molecular Biology, Breeding for Resistance. H. Czosnek, ed. Springer, The Netherlands.

71. Vidavsky, F., Leviatov, S., Milo, J., Rabinowitch, H. D., Kedar, N., and Czosnek, H. 1998. Response of tolerant breeding lines of tomato, Lycopersicon esculentum, originating from three different sources (L. peruvianum, L. pimpinellifolium and L. chilense) to early controlled inoculation by Tomato yellow leaf curl virus (TYLCV). Plant Breed. 117:165-169.

72. Walker, G. P., and Janssen, J. A. M. 2000. Electronic recording of whitefly (Homoptera: Aleyrodidae) feeding and oviposition behavior. Pages 172-200 in: Principles and Applications of Electronic Monitoring and Other Techniques in the Study of Homopteran Feeding Behavior. Thomas Say Publications in Entomology: Proc. Entomological Society of America. G. P. Walker, and E. A. Backus, eds. Entomological Society of America, Lanham, MD.

73. Wisler, G. C., Duffus, J. E., Liu, H. Y., and Li, R. H. 1998. Ecology and epidemiology of whitefly-transmitted closteroviruses. Plant Dis. 82:270-280.

74. Zitter, T. A., and Simons, J. N. 2003. Management of viruses by alteration of vector efficiency and by cultural practices. Annu. Rev. Phytopathol 18:289-310. 